\title{
Application of Criminal Penalties in Child Protection Law in the State Court Of Ngawi
}

Sulistyo Utomo ${ }^{1}$ and Ira Alia Maerani ${ }^{2}$

Abstract. This research aims to identify and analyze the existence of the application of criminal penalties in the handling of criminal cases Child Protection in Indonesia and analyze the effectiveness of criminal fines when viewed from the perspective of children as victims of crime.

Method used is socio-juridical using primary and secondary data. Primary data collection technique is done with the interview, and secondary data by reading, reviewing and analyzing primary legal materials, secondary legal materials, tertiary legal materials with qualitative analysis techniques, interpreted logically and systematically and drawn conclusions.

Based on the survey results revealed that the existence of the application of criminal penalties in the handling of criminal cases Child Protection in Indonesia criminal fines in criminal prospects are just as an alternative or substitute for imprisonment or confinement. And effectiveness this penalty has not run optimally because the defendant would prefer to replace the criminal penalties to imprisonment.

The conclusion of this thesis is that the implementation or execution of criminal penalties in Indonesia have not been effective or not maximized because law enforcement or judges tend to prefer the imprisonment of the criminal fines Keywords: Criminal Fines; Criminal Prison; Children.

\section{Introduction}

The increasing number of cases of crimes against children as the victim in the community reflects the lack of law enforcement in Indonesia so far. Crimes against children cause anxiety in the community, especially parents. Children who become victims of crime often experience prolonged trauma as a result of the incident.

With regard to criminal offenses against children arise because of prison sentences given to the perpetrators do not make people afraid of doing so, even many actors who committed the crime. Children must be protected so that they do not become victims of anybody (individual, group, private and government organizations), either directly or indirectly. Country through the government, has made every effort to provide the best to children in various child protection embodied in various kinds Act. Some of them are in the Constitution of 1945, Act No. 39 of 1999 on Human Rights (HAM), Act No. 17 Of 2016 regarding the Second Amendment Act No. 23 of 2002 on Child Protection to be implemented. ${ }^{3}$ Up to this time Protection Act the child itself has undergone several changes, namely Act No. 23 of 2002 on the Protection of Children,

\footnotetext{
1 Student of Master of Law, Universitas Islam Sultan Agung Semarang and Attorney, email : listyo610@gmail.com

2 Lecturer of Master of Law, Sultan Agung Islamic University (UNISSULA), Semarang

3 Arif Gosita, 1989, Masalah Perlindungan Anak, Pressindo Academy, Jakarta, p. 35
} 
as amended by Act No. 35 of 2014 on the Amendment to Act No. 23 of 2002 on Protection of Children and Last Modified by Act No. 17 Of 2016 concerning the Stipulation of Government Regulation in Lieu of Act No. 1 of 2016 on the second amendment of Act No. 23 of 2002 into law.

Many cases of public concern relating to the crime of child protection, one example as is the case in Ngawi in East Java, a man named Sugiyanto who have intercourse to 2 (two) daughters, his neighbor Fara Juliana Saputri-old 7 (seven) years and Diyan Debita Mega Pratiwi who were aged 6 (six) years, both by Sugiyanto invited to play at home, with guile and persuasion Sugiyanto finally both girls fucked by Sugiyanto, thus making Sugiyanto trial in the State Court of Ngawi , In State Court of Ngawi Judge's decision on Thursday, August 2, 2018 Dropped criminal defendant with imprisonment for 15 (fifteen) years and a fine of Rp.1.000.000.000,

The imposition of this penalty priority to harmony between the harm caused by an offense with the amount of fine to be paid by the convict. The imposition of criminal penalties as an alternative to criminal short-term deprivation of liberty which is the principal criminal types that most rarely handed down by the judge in his discretion, especially in the practice of criminal justice in Indonesia. ${ }^{4}$

Regarding criminal penalties by lawmakers not determined a common maximum limit. In each article of the Criminal Code of the respective specified maximum limit (special) criminal penalties that can be set by the judge. If the penalty imposed by the judge, and the penalty is not paid, it is replaced with imprisonment. The length of the substitute imprisonment for at least one day and a maximum of six (6) months.

This study will highlight how the application of criminal penalties in the case of Child Protection in the State Court of Ngawi. This study will also look the effectiveness of criminal penalties in the case of child protection when viewed from the perspective of children as victims of crime.

\section{Research Methods}

To complete this study in order to be more focused and can be justified scientifically, then the writing method used, among others. ${ }^{5}$

The method used is namely juridical sociological study based on a legal provision and phenomena or events that occur in the field. Where the specification of his research is descriptive analysis means authors conducted a study that aims to give a comprehensive picture of the facts and the legal issues, the legal system related to the object of research, then pulled a certain belief took this to a conclusion. ${ }^{6}$

In scientific research there is the use of primary legal materials that legislation governing replacement imprisonment penalty, legislation governing child. There is also a secondary law, namely literature to reference books, magazines, papers, journals,

\footnotetext{
4 Andi Hamzah, Sistem Pidana dan Pemidanaan di Indonesia, Op. Cit., p. 56

5 Soejono Soekanto, 1198, Pengantar Penelitian Hukum, UI Pres, Jakarta, p. 43

6 Soerjono Soekanto and Sri Mamudji, 2003, Penelitian Hukum Normatif Suatu Tinjauan Singkat,, King Grafindo Persada, Jakarta, p.14.
} 
documents, workshops and seminars that have relevance. ${ }^{7}$ Tertiary legal materials are also used in this research where the legal materials have been of instructions and explained to primary legal materials and secondary law such as legal dictionaries, encyclopedia. ${ }^{8}$

The analysis in this journal writing using Qualitative analysis techniques that is to say where the data obtained is then arranged systematically so that it will be obtained a comprehensive overview, in which the data will be presented descriptively, with the expectation can be obtained comprehensive picture of the problems studied. ${ }^{9}$

\section{Results and Discussion}

\subsection{The Application Of Criminal Penalties In The Case Of Child Protection In The State Court Of Ngawi}

The application of criminal penalties in the case of child protection in State Court of Ngawi in this study, the authors performed an analysis of felony obscenity case ruling againts minors with No. 141 / Pid.Sus / 2018 / PN.Ngw, which adjudicate Sugiyanto as Yanto Bin Karno with the victims named Diyan Debita Mega Pratiwi and Fara Juliana Saputri aged about 6 years and 9 months.

\subsubsection{Case position}

The incidence of abuse begins on the day and date can not be determined again in March 2018, located in the hamlet Ngisor RT. 02 RW. 03 District of Paron Ngawi. Chronology is when the accused to call witnesses Fara Juliana Saputri who was playing behind the house of the defendant, the defendant took the witness Fara Juliana Saputri fit into one of the rooms at home defendant, and the defendant told the witness Fara Juliana Saputri to undress it, after the defendant fingering witness Fara Juliana Saputri then the defendant enter into a state genitals tightened into genitals witness and defendant Fara Juliana Saputri move her body up and down, after feeling satisfied then the accused told the witness Fara Juliana Saputri wearing pants back and the accused told the witness Fara Juliana Saputri order not to tell the incident to anyone. A few days later from the first incident, the witness Fara Juliana Saputri and the witness Diyan Debita Mega Pratiwi play around the house of the accused. Then defendant summoned both of them and invite witnesses Fara Juliana Saputri and witnesses Diyan Debita Mega Pratiwi into the room defendant and acts of abuse against them. The act was repeated again during the 4 (four) times in March to April 2018. Fara Juliana Saputri witnesses and witnesses Diyan Debita Mega Pratiwi play around the house of the accused. Then defendant summoned both of them and invite witnesses Fara Juliana Saputri and witnesses Diyan Debita Mega Pratiwi into the room defendant and acts of abuse against them. The act was repeated again during the 4

\footnotetext{
7 Amiruddin and Zainal Asikin, 2013, Metode Penelitian Hukum, PT. RajaGrafindo Persada, Jakarta, p. 32.

8 Ibid.,

9 Eko Sugiarto, 2015, Menyusun Proposal Penelitian Kualitatif, Skripsi dan Tesis, Asylum Media Yogyakarta, p. 9.
} 
(four) times in March to April 2018. Fara Juliana Saputri witnesses and witnesses Diyan Debita Mega Pratiwi play around the house of the accused. Then defendant summoned both of them and invite witnesses Fara Juliana Saputri and witnesses Diyan Debita Mega Pratiwi into the room defendant and acts of abuse against them. The act was repeated again during the 4 (four) times in March to April 2018.

\subsubsection{Demands Prosecution}

Regarding the demands of the public prosecutor against child abuse cases committed by the defendants Yanto hin as Sugiyanto Karno for victims Fara Juliana Saputri and Diyan Debita Mega Pratiwi, The public prosecutor appealed to the Judge of State Court of Ngawi and adjudicates the case is to be decided:

- The defendant stated Sugiyanto as Yanto Bin Karno proven legally and convincingly guilty of committing a criminal offense in violation of Article 81 paragraph (2) of the Law of the Republic of Indonesia Number 17 Of 2016 concerning the Stipulation of Government Regulation in Lieu of Act No. 1 of 2016 on the Second Amendment Act Act No. 23 of 2002 on Child protection be Jo Law Article 65 paragraph (1) of the Criminal Code as the prosecutor in the indictment.

- Give punishment against the defendant Sugiyanto as Yanto Bin Karno criminal punishment for 15 (Fifteen) years reduced during the defendants were arrested by order the defendant remained in detention and a fine of Rp. 1,000,000,000 (One Billion Rupiah) Subsidiary 4 (Four) months in prison.

\subsubsection{Judge consideration}

Regarding Court Judge considerations can be taken several fundamental points that include to strengthen the Public Prosecutor court indictment has been filed written evidence in the form of Post mortem Hospital Widodo Ngawi, on behalf of Diyan Debita Mega Pratiwi No. 02328 / RS.WDD / IV / 2018 and VICUIM mortem Hospital Widodo Ngawi, on behalf of Fara Juliana Saputri No. M9 / RS WDD / IV / 2018 Date 9 April 2018 signed by dr. Nurul Faizah.

To strengthen the Public Prosecutor court indictment has also filed evidence in the form:

- 1 (one) piece pink dress

- 1 (one) pants in blue

- 1 (one) piece dress blue color image ponies

- 1 (one) t-shirt in yellow color

- 1 (one) trousers in white color

- 1 (one) small jar contents mixed handbody soap.

- 1 (one) handbody

- 1 (one) shirt in white singlet.

- 1 (one) blue floor mattresses.

- 1 (one) shorts blue gray

- 1 (one) in beige pants.

Judge of State Court of Ngawi stated that the elements of defendant contained in Article 81 paragraph (2) of the Act No. 17 Of 2016 concerning the Stipulation of 
Government Regulation in Lieu of Act No. 1 of 2016 on the Second Amendment Act No. 23 of 2002 on form the Child protection Act in conjunction with article 65 paragraph (1) of the Criminal Code.

In consideration of the verdict passed a decision stating the defendant Sugiyanto as Yanto bin Karno proven legally and convincingly guilty of committing a criminal act of intercourse or sexual abuse. The first convict the accused Sugiyanto as Yanto bin Karno by imprisonment for 15 (Fifteen) years and a fine of Rp. 1.000.000.0000, - (one billion rupiah) and if the fine is not paid to be replaced by imprisonment for two (2) years prison. Setting the second period of arrest and detention that have been undertaken defendant deducted entirely from the sentence imposed. Third charge the defendant to pay court costs in this case amounted to Rp. 2000 - (two thousand rupiah).

The decision of judges who adjudicate on Case No. 141 / Pid.Sus / 2018 / PN.Ngw studied the theory of raised by Gustav Radbruch then things can be analyzed as follows:

- From the aspect of "justice"

Based proposed by Adiaty Rovita, $\mathrm{SH}$, which is a Judge who examine and decide in a criminal case No. 141 / Pid.Sus / 2018 / PN.Ngw on behalf of the defendant Sugiyanto as Yanto bin Karno from interviews conducted by the author expressed "regret and acknowledgment guilt of a defendant in the trial is a major factor to give leniency for the defendant, the defendant's remorse pronounced in the trial are expected defendant can improve his behavior and no longer committing a crime in the future

- From the aspect of "expediency"

Aspects of the law does not benefit regardless of how the effectiveness of a kind of punishment for the accused, the victim, and society in general. The extent to which the effects of the imposition of criminal penalties against the accused. According to the research, a criminal fine of Rp. 1.000.000.000, - (One milyarr rupiah) is large enough for the defendant and is expected to provide a deterrent effect against the accused.

- From the aspect of "legal certainty"

The enforcement of a law become a major factor in the aspect of "rule of law", the imposition of the same law for everyone and no one can hide or run from the law, even for an elderly mother though. Often in the community raised an opinion that if the elderly should not be punished or forgiven only when committing a crime.

Of 3 (three) legal purpose or value of the legal basis, if connected with Decision No. 141 / Pid.Sus / 2018 / PN.Ngw on behalf of the defendant Sugiyanto as Yanto bin Karno, then, according to research aspects of expediency more likely or dominant ruling, where the aspect of fairness and legal certainty be displaced, this is in line with what was raised by Gustav Radbruch, if the value of justice is more dominant, then he will shift the value of the benefit or value of the rule of law, and vice versa if the benefit is more dominant, then he will shift the values of justice, or the value of legal certainty.

Then the verdict the judges who adjudicate on Case No. 141 / Pid.Sus / 2018 / PN.Ngw sentencing in the case studied with the objective of sentencing theory 
refers to the theory of absolute convictions that to give a reply to mistake defendant, not as a tool to improve self-defendant in which the judge did not see reasons relieve the defendants.

\subsection{The Effectiveness Of Criminal Penalties In The Case Of Child Protection When Viewed From The Perspective Of Children As Victims Of Crime}

In connection with the effectiveness of criminal law penalties in the decision on Case No. 141 / Pid.Sus / 2018 / PN.Ngw relate to criminal law policy where it is attributed by the authors to the theory of criminal law policy that will be able to cope with similar problems. Where such decision is implemented through the stages of the functioning of the law, namely:

- Criminal material (substantial) In the decision on Case No. 141 / Pid.Sus / 2018 / PN.Ngw Judge has the right to use and apply article imposed, namely Article 81 paragraph (2) of the Act No. 17 Of 2016 concerning the Stipulation of Government Regulation in Lieu of Act No. 1 of 2016 on the Second Amendment Act No. 23 of 2002 on the protection of children becoming Act.

- The formal criminal law (the law of criminal procedure) In the decision on Case No. 141 / Pid.Sus / 2018 / PN.Ngw the process starts from State Court of Ngawi received a letter of delegation of the case until the verdict among others

- Examination of the defendant's identity

- reading of the indictment

- Exception

- verification

- The reading of the warrant

- Pledoi

- verdict

- Implementation of criminal law

In the decision on Case No. 141 / Pid.Sus / 2018 / PN.Ngw defendants were sentenced to imprisonment of 15 (fifteen) years in prison and a fine of Rp. $1,000,000,000$ (one billion rupiah) provided that if the fine was not paid to be replaced with imprisonment of 2 (two) months in prison where in the minutes of the execution of court decisions No. print- / 0.5.33 / Euh.3 / 2018 in which the defendant was added Prisons Correctional Ngawi to undergo criminal for 15 (fifteen) years of time served and an additional imprisonment for two (2) months because the defendant was not able to pay the penalty of criminal penalties.

Effectiveness criminal fine views of children as victims of crime according to the authors do not provide a sense of justice for victims of crime, because if the penalty is paid by the defendant of the money goes into the state treasury.

In anticipation of a penalty in cases of abuse against children may actually be through a request for restitution to be more effective where stipulated in Government Regulation No. 43 of 2017 on Restitution For Children Who Become Crime Victims. 
Restitution is the payment of compensation charged to the offender by a court decision that is legally binding. Loss of material and non-material suffered by victims can be converted into rupiah and the victim filed a parent or guardian to obtain restitution. The hope with the filing of restitution is the children who are victims of crime get compensation from the offender.

The restitution rights are rights that applied for the victim. Request can be deposited through investigation, through the prosecutor, and then submitted to the court along with the handling of the case. ${ }^{10}$ However, generally speaking according to the author's restitution keep the problem. The problem of restitution or compensation which is charged to the offender. Imposition of damages against the perpetrator was reasonable, but the problem involves a very long process until the verdict of the judges in the Court. A further problem is the execution. Given restitution imposed on perpetrators, it becomes a problem if the offender was not able, or not willing to carry out the execution.

The above problem occurs because the concept of compensation for the victims are still relying on the concept of restitution are charged directly to the perpetrators. This paradigm should begin to change, at least for victims of certain crimes, specifically for the victims of certain crimes beyond the paradigm should no longer rely on the obligation of (the) direct perpetrators, but from the state for the provision of compensation.

In case Number 141 / Pid.Sus / 2018? PN.Ngw above during the trial against the defendant the right to restitution for victims not included in the prosecution file, because there is no request from the victim.

\section{Closing}

\subsection{Conclusion}

Criminal penalties stipulated in Article 30 paragraph (1) to paragraph (6) of the Penal Code Article 30 paragraph (2), which states If the penalty is not paid, it was replaced by imprisonment, criminal drop the verdict Case Number 141 / Pid.Sus / 2018 / PN.Ngw according to the author is very good, but in terms of execution less effective because the defendant did not pay the fine because the value of fines is large enough and not comparable to the state of the economy.

\subsection{Suggestion}

The judge in imposing criminal penalties should also see the ability of the defendant, because criminal fined heavily dependent on the ability and willingness of the defendant to pay compensation for the judge's decision imposed upon him.

\section{References}

[1] Arif Gosita, 1989, Masalah Perlindungan Anak, Akademi Pressindo, Jakarta.

10 Interview with Adiaty Rovita, SH, Ngawi District Court Judge, dated January 9, 2020 
[2] Amiruddin and Zainal Asikin, 2013, Metode Penelitian Hukum, PT. RajaGrafindo Persada, Jakarta.

[3] Eko Sugiarto, 2015, Menyusun Proposal Penelitian Kualitatif, Skripsi dan Tesis, Suaka Media, Yogyakarta.

[4] Soejono Soekanto, 1981, Pengantar Penelitian Hukum, UI Pres, Jakarta.

[5] Soerjono Soekanto and Sri Mamudji, 2003, Penelitian Hukum Normatif Suatu Tinjauan Singkat, King Grafindo Persada, Jakarta. 